\title{
Da compaixão à inocência: Nietzsche e Schopenhauer em torno da questão do egoísmo
}

\author{
From Compassion to Innocence: \\ Nietzsche and Schopenhauer Around \\ the Issue of Selfishness
}

*Jelson Roberto de Oliveira

\begin{abstract}
Resumo: Pretende-se demonstrar nesse trabalho como Nietzsche formula, nos escritos que formam o segundo período de sua produção filosófica, uma crítica à moral da compaixão proposta por Schopenhauer. Para isso, far-se-á uma revisão das teses schopenhaurianas segundo as quais o egoísmo é o motivo antimoral por excelência e, contrariamente, o altruísmo é a base legítima da moralidade. Analisar-se-á, também, o procedimento usado por Nietzsche para, de um lado, criticar esse ideal e, de outro, chegar à inocência como principal resultado de seu programa filosófico.
\end{abstract}

Palavras-chave: Nietzsche. Schopenhauer. Egoísmo. Compaixão. Inocência.

\begin{abstract}
We intend to demonstrate in this work as Nietzsche formulates, in the writings that form the second period of his philosophical production, a critique to the moral of compassion proposed by Schopenhauer. For this, we'll make a review of the Schopenhauer's theses under which selfishness is the reason antimoral par excellence and, in contrast, altruism is the legitimate basis of morality. We will analyze also the procedure used by Nietzsche to, on one hand, criticize this ideal, and the other, reaching the innocence main result of his philosophical program.
\end{abstract}

Keywords: Nietzsche. Schopenhauer. Selfishness. Compassion. Innocence.

\footnotetext{
* Professor do Programa de Pós-Graduação em Filosofia da Pontifícia Universidade Católica do Paraná.<jelsono@yahoo.com.br>.
} 


\section{Introdução}

A afirmação de que o mundo é Vontade (Wille) e aparece ao sujeito como Representação (Vorstellung) leva Schopenhauer à determinação da existência como manifestação de um querer metafísico caracterizado pelo egoísmo. Como essência do mundo, a Vontade é analisada pelo filósofo através de sinédoque, ou seja, de uma extensão analógica baseada na intuição, a partir do querer humano, que está - e é - corpo, ou seja, o corpo humano torna-se um "lugar" central para a possibilidade de compreensão da Vontade: "A Vontade é o conhecimento a priori do corpo; o corpo é o conhecimento a posteriori da Vontade" (MVR ${ }^{1}$, p. 134). O corpo dá visibilidade para a Vontade que nele se apresenta como uma pulsão (Trieb) e busca cega pela afirmação radical de si mesma enquanto vida. A Vontade age em busca de mais lugares no espaço, de prolongamento no tempo e em ação sobre outros fenômenos, conforme a lei de causalidade para a sua conservação e expansão e no caso do corpo, ela age como um eu que se revela como manifestação da Vontade. Sendo assim, o corpo faz do eu também Vontade fazendo coincidir o existir com o querer ${ }^{2}$. Como indivíduos, somos marcados pelo querer e esse é um sinal premente de nossa existência. E porque quer, o homem constitui-se como pensamento, ou seja, encontra o seu eu, modelo segundo o qual, entretanto, a Vontade mantém uma primazia radical em relação ao intelecto.

A Vontade é independente das "formas da intuição, [...] o tempo, o espaço e a causalidade" (MVR, p. 74), ou seja, a Vontade, como coisa-emsi do mundo permanece fora do tempo, do espaço e alheio à causalidade e, sendo assim, sua caracterização passa pela "tarefa de separar a coisa-emsi de seus fenômenos [e] prossegue por meio da determinação negativa da essência em relação às formas do conhecimento" (MVR, p. 81). Isso significa, segundo Schopenhauer, que falar da Vontade é impossível a não ser inversamente em relação à Representação, dizendo, portanto, o que ela não é: como não submetida ao tempo, portanto, à finitude, ela é eterna; como não contida no espaço, ela não é múltipla e, portanto, é unidade; e como não relacionada à necessidade da causalidade, ela é liberdade.

Essas afirmações preliminares e bastante horizontais quanto às possibilidades de análise de seu conteúdo, levam à compreensão da existência como uma luta eterna e implacável de quereres, uma guerra

\footnotetext{
${ }^{1}$ Nesse artigo usaremos as seguintes siglas: MVR (O Mundo como vontade e como representação); SFM (Sobre o fundamento da moral); EH (Ecce Homo); HH (Humano, demasiado humano); GM (Para a genealogia da moral); e A (Aurora).

2 "Toda a antropologia de Schopenhauer gravita em torno de uma negação do tradicional dualismo, o do corpo e do espírito, e da afirmação de um novo dualismo, o do intelecto e o do querer" (LEFRANC, 2002, p. 129)
} 
constante de autoafirmação egoísta de tudo o que existe, uma busca incessante pela satisfação dos desejos e pela autopreservação: "toda ação cujo fim último é o bem-estar e mal-estar do próprio agente é uma ação egoísta" (SFM, p. 126). Como marca da Vontade, o egoísmo metafísico de Schopenhauer é analisado como busca pela autopreservação da Vontade. Isso faz do egoísmo o motor da vida como Vontade e o motivo da luta árdua e cheia de sofrimento, já que a expansão da Vontade de um ser individual encontra resistência na de outro. Guiado pelo egoísmo, o homem busca seu próprio bem-estar, mas as condições materiais para essa realização são limitadas, o que leva à desvantagem de outrem.

Ora, como veremos a seguir, essas ideias serão criticadas por Nietzsche no momento de afastamento de seu mestre e de sua proposta moral baseada na compaixão, principalmente a partir dos escritos de 1876, justamente os textos que formam o chamado segundo período de sua produção filosófica (e que, ademais, vão até 1882). Nietzsche não apenas critica o ideal da compaixão por sua base altruísta, como recupera ou revitaliza o egoísmo a partir de uma análise fisiopsicológica que, por basear os sentimentos morais numa necessidade, acaba por conduzir à inocência de todos os atos humanos - livrando o egoísmo da visão tradicional de culpa, portanto. O mote central dessa reflexão está ligado à afirmação de si, principal elemento para que seja possível pensar uma espécie de moral em Nietzsche.

\section{Schopenhauer e o egoísmo como motivação antimoral por excelência}

No seu Sobre o fundamento da moral, texto como se sabe, escrito em resposta à questão proposta pela Academia Real Dinamarquesa de Ciências de Copenhague, em 1840, Schopenhauer afirma que "egoísmo e valor moral simplesmente excluem-se um ao outro" (SFM, p. 133), acrescentando que "se uma ação tiver um fim egoísta como um motivo, então ela não pode ter nenhum valor moral" (SFM, p. 133). Na sua tentativa de fundamentação da ética no valor absoluto da compaixão, o autor de $\mathrm{O}$ mundo como vontade e como representação parte de uma análise das chamadas "motivações antimorais" (SFM, p. 120), entre as quais está o egoísmo. Para Schopenhauer, "a motivação principal e fundamental, tanto no homem como no animal, é o egoísmo, quer dizer, o ímpeto para a existência e o bem-estar" (SFM, p. 120). O mundo marcado pela Vontade, enquanto sua essência, carrega a marca do egoísmo, em termos metafísicos e cosmológicos, porque a Vontade é a força regente dos fenômenos ilusórios do mundo, marcada pela busca interesseira de si mesma e sua completa autorrealização. A afirmação do egoísmo é um ímpeto presente no homem e nos animais e remete a um "interesse 
próprio", referindo-se a um tipo de egoísmo "guiado pela razão, que o torna capaz, por meio da reflexão, de perseguir seu alvo de modo planejado" (SFM, p. 120). Ao chamar animais e homens de egoístas, o filósofo refere-se a um tipo de motivação não simplesmente interesseira, mas egoísta no sentido de que ela se refere ao "âmago" e ao "ser mais íntimo deles" com os qual se tornam "idênticos" (SFM, p. 120). Tratase de um motor de potência tal que todas as ações dos animais e dos homens sejam reconhecidas como derivadas do egoísmo, servindo ele de explicação para o fundamento de qualquer uma de suas ações.

O egoísmo, assim, como parte da natureza mesma dos animais em geral, é totalmente sem limites e fomenta todas as atitudes que visam a persistência vital dos animais, sendo descrito como a frequência máxima de todas as atitudes que visam a autoconservação, a fuga da dor, a busca do bem-estar e do prazer, bem como o desenvolvimento das aptidões para os gozos vitais. O homem "quer o quanto possível, desfrutar tudo, ter tudo" e como isso se torna impossível, quer então "dominar tudo": "Tudo para mim e nada para o outro" (SFM, p. 121) seria a máxima das motivações antimorais que fundam todos os comportamentos no mundo e tornam o egoísmo algo "colossal" que "comanda o mundo" (SFM, p. 121). Guiado pelo egoísmo, o homem se torna o centro do mundo, "relaciona tudo a si próprio" (SFM, p. 121) em busca de sua completa autoafirmação, pensando sempre em seu interesse e sacrificando a ele todo o resto. Dada a imediatez com que cada indivíduo lida consigo mesmo (em contraposição à mediatez do outro), ele afirma peremptoriamente o seu direito único e absoluto sobre seu próprio eu, desfazendo-se de qualquer tendência que o faça destituir-se de tal consciência de si que se torna "para si mesma o mundo todo" (SFM, p. 122). Já que tudo o que existe fora do sujeito não passa de algo mediato, ou seja, uma mera representação, aquilo que lhe é próprio como autoconsciência torna-se logo o único a ser afirmado e seu mundo central: "Por isso mesmo cada um é para si tudo no todo, encontra-se como possuidor de toda a realidade, e nada pode ser mais importante para ele do que ele próprio" (SFM, p. 122). Como vontade de viver, o egoísmo cresce por todo lado, espremido, inclusive, pela ameaça da própria morte (cuja visão aparece como a morte de todo o mundo, dada a condensação de suas evidências na autoconsciência que faz o eu sentir-se como o único mundo existente).

Para Schopenhauer, mesmo as formas cotidianas da cordialidade e da ajuda mútua carregariam uma "hipocrisia reconhecida" (SFM, p. 123) que muito mal conseguiria disfarçar o egoísmo sempre presente. A preferência por essa hipocrisia é explicada pelo maior horror representado pela visão do que ela esconde, ou seja, pelo egoísmo que espreita sob o seu véu. É para ele que, aliás, as instituições sociais - Schopenhauer 
cita diretamente o Leviatã de Hobbes e a tese de que o Estado surge do medo recíproco frente aos horrores do egoísmo à solta representado pela guerra geral entre todos - existem, como via de negativação desse impulso antimoral.

Dada a confessada noção hiperbólica do egoísmo apresentado por Schopenhauer, ele também afirma que "o egoísmo é a primeira e a mais importante potência, embora não seja a única, que a motivação moral tem de combater" (SFM, p. 124). A descrição apavorante do cenário motivado por tal impulso faz, portanto, com que o autor eleja a luta contra ele como o centro da moralidade. Criticando a fundamentação moral kantiana, chamada indiretamente de "sutileza aguda" e de "bolha de sabão apriorística" (SFM, p. 124), ou mesmo das "astúcias, sutilezas, afirmações apanhadas no ar e bolhas de sabão apriorísticas que os sistemas até então quiseram fazer de fonte para o agir moral e de fundamento para a ética" (SFM, p. 132), Schopenhauer afirma a necessidade de eleger um motivo moral de evidência e eficácia reais. Para Lefranc (2002, p, 153) Schopenhauer compreende que as "fórmulas kantianas se embaralham em expressões estranhas, noções sutis que dificilmente ocultam a sua origem teológica". Portanto, não basta buscar no pensamento a origem da moral, mas antes, no próprio coração, segundo a afirmação de Vauvenargues, citada por Schopenhauer nos Parerga; "os grandes pensamentos veem do coração" (I, A filosofia e seu método, 9). Assim, na busca do fundamento, o filósofo pretende dar consistência a elementos morais que, de resto, não passariam de mero enunciado racional. Longe de negar os motivos morais, portanto, tratase mesmo de fundamentá-los. O primeiro desses motivos é justamente a virtude da justiça, "a primeira e bem própria virtude cardinal" (SFM, p. 124). Mas trata-se ainda, como se sabe, de um valor negativo: "nada fazer que possa de algum modo aumentar o sofrimento do mundo" (LEFRANC, 2002, p. 158) ou, nas palavras de Schopenhauer, "O fim do Estado é que ninguém sofra injustiça; o fim da doutrina moral é que ninguém cometa injustiça" (SFM, p. 149).

Mas não sendo o egoísmo a única força contrária à moralidade que deve ser combatida, o autor se propõe a fazer uma análise da origem e das gradações dos sentimentos de malevolência ou ódio que surge como uma potência ao lado do egoísmo. Se este pode conduzir "a todas as formas de crimes e delitos" seus prejuízos a outrem devem ser entendidos como meios e não fins em si mesmos, justamente o contrário do que ocorre no ódio, que faz desses prejuízos fins em si mesmos - "alcança-los é o que dá prazer" (SFM, p. 126), o que faz deles uma alta potência de maldade moral. Uma análise ética dos vícios derivados do ódio e do egoísmo faria ver como do segundo derivariam "a avidez, a glutonaria, a intemperança, 
a luxúria, o interesse próprio, a avareza, a cobiça, a injustiça, a dureza do coração, o orgulho, a vaidade etc." (SFM, p. 123), enquanto do primeiro adviriam "o ciúme, a inveja, a malevolência, a maldade, a alegria maligna, a curiosidade indiscreta, a maledicência, a insolência, a petulância, o ódio, a ira, a traição, o rancor, o espírito de vingança, a crueldade etc." (SFM, p. 124). Para Schopenhauer, a predominância de um desses sentimentos ou ainda a sua ausência, na forma de motivos morais, classificariam eticamente os caracteres.

Com essa taxonomia das potências antimorais, o filósofo pretende ter descrito o lado obscuro da natureza humana e com isso, almeja ter mostrado quão difícil torna-se, frente a essa realidade, o encontro de um fundamento motivacional para as ações morais do homem, já que essas tendências se encontram absolutamente "enraizadas na sua natureza" (SFM, p. 127). A própria tomada daquilo que Schopenhauer chama de "maquinaria de um outro mundo" (SFM, p. 127), ou seja, o mandamento dos deuses e as ameaças de castigo eterno num outro mundo, testemunha a dificuldade dessa tarefa. Supondo-se que ela obtivesse sucesso quanto a sua inculcação na natureza humana, de forma mais eficaz do que qualquer procedimento institucional, tal como a justiça ou mesmo a polícia, mesmo aí não se poderia falar de uma disposição moral, já que mesmo aí, em ações derivadas da atração da recompensa, da ameaça do castigo ou mesmo troca por benesses a longo prazo não estariam senão fundadas ainda no egoísmo. As religiões, enquanto "metafísicas do povo" (SFM, p. 128) acabam fomentando essas atitudes como suficientes, todavia ainda marcadas por interesses egoístas. Schopenhauer recusa o simplismo da argumentação para fazer ver que o egoísmo se estabelece amplamente nas ações humanas no que diz respeito aos seus motivos. Ao abrir mão das narrativas religiosas, o filósofo pretende elucidar e demonstrar quais os critérios que fundam as ações de tal forma que elas possam ser consideradas morais. Isso lhe conduz, como se sabe, à afirmação da compaixão como fundamento moral, posto que ela estaria baseada no mais puro e irredutível serviço desinteressado ao outro. Com isso, o filósofo não apenas estabelece o valor fundamental da moral, mas também o critério filosófico de seu fundamento, algo que faltaria às religiões.

$\mathrm{Na}$ busca por esse critério que doaria valor moral às ações humanas, o autor parte da afirmação de que é possível - ainda que não empiricamente - concordar a respeito da existência de "pessoas verdadeiramente honestas" (SFM, p. 130) que agem de forma desinteressada e que "ajudam e dão, fazem e renunciam sem ter outro intuito em seu coração que o de ajudar a outrem cuja necessidade eles veem" (SFM, p. 130). Seria possível reconhecer, assim, que Schopenhauer vislumbra na experiência 
moral, a despeito de todo seu pessimismo, uma "dupla possibilidade de maldade fundamental e de bondade fundamental" (LEFRANC, 2002, p. 155). Mesmo com a presença de todos os motivos antimorais que marcam a existência, é possível pensar que determinadas ações são guiadas pela pura bondade, algo que o filósofo acredita ser possível provar empiricamente em inúmeros exemplos cotidianos: "todo ser humano tem em seu caráter, segundo Schopenhauer, algum elemento de compaixão" (JANAWAY, 2003, p. 118), ainda que haja "vastas diferenças" nos graus de compaixão que cada ser humano é capaz de manifestar. Por isso, os três móveis morais (o egoísmo, a maldade e a compaixão) podem ser experimentados em cada indivíduo em "proporção diferente e incrivelmente diferente" (SFM, p. 194), vindo a definir os caracteres humanos. A compaixão "é o incentivo de buscar o bem alheio (ou de aliviar o sofrimento de outrem)"; a maldade "é o incentivo de buscar o sofrimento alheio"; e o egoísmo "o incentivo de buscar o próprio bem-estar" (JANAWAY, 2003, p. 119).

Caso não se partisse dessa convicção, faltaria à própria moral, segundo Schopenhauer, um fundamento viável e eficaz, e também um "objeto real" (SFM, p. 130). As ações desinteressadas, portanto, ainda que raras e de difícil percepção empírica, são as únicas às quais se poderia admitir realmente um valor moral e com isso, ao mesmo tempo, estaríamos excluindo da moralidade as ações egoístas e interesseiras: "A ausência de toda motivação egoísta é, portanto, o critério de uma ação dotada de valor moral" e esse critério excluiria do campo moral qualquer ação na qual houvesse um único indício de interesse próprio.

A pergunta do autor é sobre o fundamento dessas ações: uma pergunta sobre o que pode ser apontado como "genuína motivação moral" desse tipo de ação. É essa a prova fornecida pelo cabedal filosófico-argumentativo do autor, o qual pretende fazê-lo de forma séria e indubitável, a fim de não apenas sugerir o fundamento (como fizeram os sistemas até então, segundo ele), mas, sobretudo, prová-lo. Nascem daí os nove [9] pressupostos que, no geral, valem como axiomas fundamentais dessas tentativas e que podem ser reduzidos no seguinte: todas as ações ocorrem devido a motivos que estão ligados ao bem-estar ou ao mal-estar, os quais são seus fins últimos tanto quanto ao agente da ação quanto ao destinatário dela. Ora, sendo assim, o sexto axioma prevê que toda ação guiada pelo bem ou mal-estar do agente é egoísta, de tal forma que "egoísmo e valor simplesmente excluem-se um ao outro" (SFM, p. 133) e, consequentemente, toda ação moral tem sempre em vista e só adquire significação se estiver relacionada aos outros, ou seja, é esse o critério moral por excelência que possibilitaria avaliar positivamente ou condenar uma ação humana. É o outro enquanto fim da 
ação moral que detém o poder de doar-lhe valor e Schopenhauer afirma que é nesta finalidade alheia ao agente e em franco benefício, proveito e contentamento de um outro (SFM, p. 135) que a ação encontra neste outro o seu motivo. Caso tenha em vista o bem estar apenas do agente, essa ação será sempre egoísta e isso não apenas diretamente (o que é mais fácil de ser identificado), mas também indiretamente, no caso, por exemplo, de que o agente "espere de uma ação algum êxito longínquo para si mesmo, neste ou naquele mundo, ou quando se visa sua honra, sua fama entre as pessoas ou o respeito de qualquer um, a simpatia do observador e assim por diante" (SFM, p. 134). Inclui-se nesse tipo de ação egoísta e sem valor moral, as várias ocasiões em que o cumprimento de regras morais apenas devido às vantagens ou ameaças que elas implicam.

Schopenhauer não deixa dúvidas, então, de que o motivo genuinamente moral de uma ação é o outro, e é ele que passa a mover a vontade do agente num grau de intensidade tal que a vontade alheia se torne a vontade própria: "quero imediatamente o seu bem e não o seu mal, tão diretamente como se fosse o meu" (SFM, p. 135) e isso implica que o agente tenha a capacidade de sofrer com o mal-estar desse outro, de sentir o mal de outrem como próprio e queira o seu bem também como próprio. Trata-se de uma necessidade de identificação que suprima a original diferença entre o agente e o outro da ação, diferença, aliás, que funda o egoísmo. É, pois, através do conhecimento do outro, ou melhor, da representação do outro que essa identificação pode ocorrer e a isso, justamente, Schopenhauer chama de compaixão:

É o fenômeno diário da compaixão, quer dizer, a participação totalmente imediata, independente de qualquer outra consideração, no sofrimento de um outro e, portanto, no impedimento ou supressão deste sofrimento, como sendo aquilo em que consiste todo o contentamento e todo o bem-estar e felicidade. Esta compaixão sozinha é a base efetiva de toda a justiça livre e de toda caridade genuína. (SFM, p. 136)

É essa capacidade de sofrer-com, de partilhar a dor alheia na forma de uma representação que se efetiva como moralidade através da justiça e da caridade, rompendo com o egoísmo vigente, que daria um fundamento verdadeiro e indiscutível para a ação moral, de forma que tanto o bem quanto o mal do outro sejam sentidos como próprios e a diferença entre o eu e o outro seja diluída de forma definitiva. Rompe-se então "a parede divisória que [...] separa inteiramente um ser de outro ser, e vemos o não-eu tornar-se numa certa medida o eu" (SFM, p. 135), devolvendo ambos ao cenário enigmático da Vontade una. Trata-se, afirma o autor, do "grande mistério da ética", seu "fenômeno originário e o marco além do qual só a especulação metafísica pode arriscar um passo" (SFM, p. 136). 
A conclusão de Schopenhauer é a de que existem apenas três motivações fundamentais para as ações humanas: “a) egoísmo, que quer seu próprio bem (é ilimitado); b) maldade, que quer o mal alheio (chega até à mais extrema crueldade); c) a compaixão, que quer o bem-estar alheio (chega até a nobreza moral e a generosidade)" (SFM, p. 137). Obviamente, para o autor, as ações que tem motivações do terceiro tipo são as únicas às quais é possível chamar de ações com valor moral. Além disso, Schopenhauer destaca que as ações que nascem dessa terceira motivação são despertadas pelo sofrimento do outro, já que frente a sua felicidade o agente tende a permanecer indiferente. É a dor, portanto, e o sofrimento alheio, "de que faz parte toda falta, carência e necessidade e mesmo todo desejo" (SFM, p. 138) que são "o positivo", ou seja, "aquilo que é sentido imediatamente" (SFM, p. 138). A dor é positiva no sentido de que ela, sendo alheia, se manifesta por si mesma e desperta o interesse direto de que o agente dela participe. $\mathrm{O}$ sofrimento do outro estimula a ação moral dos indivíduos porque ele perturba e exige uma ação como resposta a essa identificação. Não estamos guiados por uma ilusão, quando isso ocorre, afirma Schopenhauer, mas por uma perturbação despertada pela dor alheia: "sofremos com ele, portanto nele, e sentimos sua dor como sua e não temos imaginação de que ela seja nossa" (SFM, p. 140), mas ainda, quanto mais sabemos que essa não é a nossa situação, pelo aumento do contraste, mais somos perturbados por ela.

A máxima moral de Schopenhauer passa a ser analisada a partir da justiça e da caridade porque está baseada na afirmação: "Não prejudiques a ninguém, mas ajuda a todos quanto puderes" (SFM, p. 140). Mas essas argumentações ainda deixaram muitas dúvidas quanto à sua evidência empírica, malgrado a insistência com que o autor de $O$ mundo como vontade e como representação defende sua tese: "como a ação compassiva pode existir", pois "se a ação é sempre um empenho corporal do indivíduo com vistas a um dado fim pessoal, a compaixão, que supostamente é o único incentivo moral genuíno, nunca deveria impelir o indivíduo a agir" (JANAWAY, 2003, p. 120). Como absolutamente presente, o egoísmo se abate sobre o mundo com todas as suas forças e com uma intensidade tal que, aparentemente, nenhum outro sentimento poderia surgir. Nesse cenário, a compaixão não seria apenas rara, mas aparentemente impossível e contrária à natureza. Segundo a sugestão de JANAWAY (2003, p. 121), a questão sobre como a compaixão pode residir na natureza humana" permaneceu para Schopenhauer algo "profundamente misterioso", o que o levou a assentar essa questão sobre fundamentos metafísicos, como elevada acima das manifestações egoístas do mundo, justamente na abolição das fronteiras entre o eu e o não-eu, ou seja, na diluição metafísica da própria vontade. Rompido o 
véu da ilusão que faz ver as coisas através do principio individuationis, o que resta é o mundo da própria Vontade, que é não-individualizante e, por isso mesmo, não particular e não egoísta. O que o olho compassivo vê, quando olha, é justamente essa força primária da Vontade. E é nisso que ele funda o sentimento compassivo, no qual pouco importa se os fins de um ou outro indivíduo são satisfeitos ou alcançados.

Sobre essa questão se debruça Nietzsche no momento de rompimento com as reses schopenhaurianas e, mesmo antes dele, essa fora a tarefa de Paul Rée, o qual pretendia dar um fundamento científico à compaixão, amparado nas teorias darwinistas.

\section{Um comentário preliminar sobre a estratégia metodológica de Nietzsche}

Nietzsche implementa, a partir de Humano, demasiado humano, um projeto de crítica à metafísica, à religião cristã e à arte romântica, como resultado do rompimento com Richard Wagner e com as teses schopenhaurianas principalmente a partir de 1876. O livro, nascido em 1878, é anunciado como o "monumento de uma crise" (EH, Humano, demasiado humano, 1) e como uma expressão da conquista da liberdade ("libertei-me com ele do que era impróprio da minha natureza") em relação aos idealismos, cuja fórmula é o "espírito livre", para quem o livro é dirigido, conforme seu subtítulo. Nietzsche fala ainda de uma "rigorosa disciplina" com a qual diz ter colocado "um fim repentino a tudo o que em mim se insinuara de 'vertigem superior', 'idealismo', 'belo sentimento' e outras feminilidades" (EH, Humano, demasiado humano, 5). O projeto, no geral, pretende desmascarar e, consequentemente, por fim à "necessidade metafísica" (EH, Humano, demasiado humano, 5) do homem e o faz usando a estratégia científica, ou seja, analisando as coisas humanas (incluídas aí a metafísica, agora vista como uma "necessidade") a partir de um método que o filósofo anuncia, já no primeiro aforismo da obra, como "filosofia histórica" e que estaria contraposta à "filosofia metafísica".

Para essa tarefa, Nietzsche conta com a influência de Paul Rée, também leitor crítico de Schopenhauer ${ }^{3}$. Quando conheceu Rée, Nietzsche

\footnotetext{
${ }^{3}$ Num texto de 1903 as posições de Rée sobre Schopenhauer são bastante explícitas. Nele Rée afirma que Schopenhauer é um "observador fino e rico de espírito", mas que comete "erros colossais" que são no fim considerados como "solução para o enigma do mundo". O texto se encontra em: RÉE, Paul. Philosophie. Nachgelassenes Werk. Berlin, 1903, "Gedanken über verschiedene Gegenstände der Philosophie", Kapitel IV, "Die Philosophie Schopenhaers", p. 290-326. Tradução italiana de D. M. Fazio. In: La scuola di Schopenhauer, Testi e contesti. A cura del Centro interdipartimentale di ricerca su Arthur Schopenhauer e la sua scuola dell'Università del Salento. Lecce: Pensa Multimedia, 2009. (Schopenhaueriana, 2).
} 
trabalhava na redação da primeira das Considerações Extemporâneas, contra David Strauss e a partir daí ambos desenvolvem uma marcante admiração e amizade, sentimento que viria a ser confirmado e fortalecido após a publicação, por parte de Rée, em 1875, da obra Observações Psicológicas ${ }^{4}$, a qual despertou imediatamente o interesse e a aprovação de Nietzsche.

Nietzsche serve-se do réealismo (intitulado em Ecce Homo de "réealismo superior" [EH, Humano, demasiado humano, 5]) para combater idealismo schopenhauriano. Essa influência é presente no que se refere ao estilo aforístico adotado por Nietzsche a partir de então, fortemente marcado pelos moralistas franceses, mas, sobretudo na interpretação de Schopenhauer. No geral, Rée partilha com Schopenhauer a crítica ao legalismo formal de Kant, mas busca em Darwin o seu apoio: o tema central ainda é o altruísmo e a pergunta sobre seu fundamento. No caso de Schopenhauer, como vimos, esse fundamento é metafísico. No caso de Rée, tratava-se de buscar um fundamento científico. Nietzsche está de acordo quanto ao procedimento, mas discorda radicalmente da premissa de que o altruísmo é o motor da ação moral ${ }^{5}$.

Na sua análise da "história dos sentimentos morais" (título do segundo capítulo de Humano, demasiado humano, nitidamente influenciado pela obra de Rée) o tema do altruísmo e, mais especificamente, da compaixão como fundamento da moral é rebatido por Nietzsche a partir de uma perspectiva de revalorização moral do egoísmo. Partindo de uma "observação psicológica" entendida como "reflexão sobre o humano, demasiado humano" ( $\mathrm{HH}, 35)$ e que conduziria a um "alívio da existência" ( $\mathrm{HH}, 35$ e 36), ainda que as posições correntes mostrem o contrário e homens como "La Rochefoucault e outros mestres franceses

\footnotetext{
${ }^{4}$ O primeiro livro publicado por Rée em 1875, Psychologische Beobachtungeni: Aus dem Nachlass Von ***, contém 475 aforismos divididos em 7 capítulos, entre os quais estão observações Sobre livros e autores, Sobre as ações humanas e seus motivos, Sobre mulheres, amor e casamento, sobre religião, sobre felicidade e infelicidade, entre outros temas diversos. Já pela lista de assuntos, não é difícil estabelecer um paralelo entre essas temáticas e aquelas analisadas por Nietzsche nos aforismos de Humano, demasiado humano. Como afirma Robin Small, na introdução à sua tradução da obra de Rée para o inglês, o tom geral da obra pode ser encontrado logo na epígrafe do livro, uma citação do filósofo francês Arthur de Gobineau (um teórico do racismo), admirado por Schopenhauer, de quem Rée se encontra bastante próximo nesse momento. A epígrafe diz: "O homem é o animal maldoso por excelência". Tratase, portanto, de uma obra na qual as ações humanas são interpretadas a partir de motivos ocultos que são sempre interesseiros e maldosos, guiados pela hipocrisia e pela vaidade e disfarçados pela virtuosidade moral algo que, em muito, dá concretude à tese geral da filosofia schopenhauriana, segundo a qual a Vontade age de modo sempre egoísta e interesseiro. Em 1885, ele publica Die Illusion der Willensfreihei: ihre ursachen und ihre folgen (A Ilusão do Livre Arbítrio: suas causas e suas consequências)

${ }^{5}$ Em Humano, demasiado humano Nietzsche partilha com Rée o interesse pelo procedimento "científico", mas já em Aurora o rompimento é iniciado para, finalmente, se tornar explícito em Para a genealogia da moral.
} 
do estudo da alma (aos quais se juntou recentemente um alemão, o autor das Observações psicológicas)" ( $\mathrm{HH}, 36)$ sejam indesejados e tidos como inconvenientes, isso já é, por si mesmo, prova de que "o ressurgimento da observação moral se tornou necessário" (HH, 37). A psicologia, assim, é apontada como "ciência que indaga a origem e a história dos chamados sentimentos morais" (HH, 37) assunto que, no geral, esteve alheio à atividade filosófica de tal forma que os erros da maioria dos filósofos "no que tange aos atos e sentimentos humanos" ( $\mathrm{HH}, 37)$ pode ser debitado nesta falha, ou seja, numa "análise errônea" (HH, 37). Nesse aforismo 37, Nietzsche dá como exemplo justamente o tema do altruísmo: "com base numa análise errônea, por exemplo, das ações ditas altruístas, constrói-se uma ética falsa; que depois, em favor desta, recorre-se de novo à religião e à barafunda mitológica e que, por fim, as sombras desses turvos espíritos se projetam até mesmo na física e em toda a nossa consideração do mundo" (HH, 37).

Nietzsche faz ver que os erros de interpretação presentes na moral a respeito do que seria o altruísmo, acabam por projetarem-se sobre a religião (no caso da cristã, fundada sob o lastro platônico), alcançando também o âmbito da ciência (Nietzsche certamente tem em mente o darwinismo). A observação psicológica de Nietzsche parte da afirmação cabal de Rée no seu Sobre a origem dos sentimentos morais, aquela que diz que "o homem moral não está mais próximo do mundo inteligível (metafísico) que o homem físico" (HH, 37), ou seja, que o homem moral deve ser entendido como próximo do homem físico ou, em outras palavras, que a moralidade tem uma proximidade e uma explicação física e não metafísica. Nietzsche acredita, nessa época, que essa afirmação bastaria para que a necessidade metafísica do homem fosse desfeita. Mas no prólogo de Para a genealogia da moral a posição de Nietzsche muda e ele chega a afirmar que lera o texto de Rée de forma radicalmente oposta: "Talvez eu jamais tenha lido algo a que dissesse 'não' de tal modo, sentença por sentença, conclusão por conclusão, como a esse livro" (GM, Prólogo, 4). Apresentando o trabalho genealógico da obra de 1887, como um amadurecimento das reflexões ainda "modestas e provisórias" (GM, I, 2) de Humano, demasiado humano, Nietzsche também deixa claro que houve uma mudança de perspectiva: se no texto da Genealogia interessa-lhe a pergunta sobre o valor da moral como um todo, nascida como uma "nova exigência" e como uma "crítica dos valores morais" ou seja, o ponto de vista do qual "o próprio valor desses valores deverá ser colocado em questão" (GM, Prólogo, 6); na obra de 1878 Nietzsche mesmo afirma estar reduzido, "ainda sem liberdade" (GM, Prólogo, 4) à pergunta sobre a "origem da moral", entendida apenas como um meio para alcançar o fim último da sua tarefa filosófica completada em Para a 
genealogia da moral. Ou seja, a desconfiança de Nietzsche em relação à moral da compaixão (e ao valor da compaixão enquanto tal), torna-se uma suspeita muito mais radical, para a qual aquela era apenas uma fraca introdução, uma desconfiança em relação à moral como um todo, ao valor da moral para a afirmação da vida. No prólogo à Genealogia, Nietzsche mostra como a pergunta sobre o valor, estando reduzida à necessidade de afrontar o "grande mestre Schopenhauer, ao qual aquele livro, a paixão e a secreta oposição daquele livro se dirigem" (GM, Prólogo, 5), reduzirase também à pergunta sobre "o valor do 'não-egoísmo', dos instintos de compaixão, abnegação, sacrifício, que precisamente Schopenhauer havia dourado, divinizado, idealizado, por tão longo tempo que afinal eles lhe ficaram como 'valores em si', com base nos quais ele disse não à vida e a si mesmo." (GM, Prólogo, 5). A pergunta sobre o valor da vida, portanto, serve de virada, fazendo Nietzsche não apenas desconfiar do valor do altruísmo, mas, sobretudo, do valor da própria moral.

É importante notar que essa mudança de perspectiva já pode ser identificada nos prefácios de 1886. No caso do Prólogo a Aurora, por exemplo, Nietzsche já apresenta a sua tarefa nas seguintes palavras:

desci à profundeza, penetrei no alicerce, comecei a investigar e escavar uma velha confiança, sobre a qual nós, filósofos, há alguns milênios construímos, como se fora o mais seguro fundamento - e sempre de novo, embora todo edifício desmoronasse até hoje: eu me pus a solapar nossa confiança na moral (A, Prólogo, 2).

É como suspeita radical da própria autoridade da moral que Nietzsche pensa agora a sua filosofia, como uma crítica da própria moral, no sentido de "tomá-la como problema, como problemática" (A, Prólogo, 3). Uma tarefa, aliás, descrita já no primeiro parágrafo desse texto, como lenta e cautelosa, porém implacável, dando a entender que é sempre da mesma atividade que se trata, mas de uma atividade contínua em direção a uma sempre maior profundeza. A lentidão, aliás, é retomada no encerramento do Prólogo, quando Nietzsche se refere ao pensamento, à escrita e à leitura como atividade de ourivesaria, que "nada consegue se não for lento" (A, Prólogo, 5) e reitera, com isso, a importância de que seu texto seja lido com vagar para que seja lido bem, de forma a descobrir o seu verdadeiro significado no contexto geral de sua crítica à mora.

A pergunta de Nietzsche recusa a velha sedução da moral que atirou a maioria dos filósofos (entre os quais, obviamente, Rousseau, Kant e Schopenhauer) na tarefa de fundamentação da moral, sem terem se colocado a pergunta sobre o valor dessa atividade. De resto, tratou-se de fanatismo e não de filosofia e no fundo, de um pessimismo em relação à 
natureza. Contra isso Nietzsche oferece uma fórmula: "a autossupressão da moral" (A, Prólogo, 4), ou seja, nele a moral, por moralidade, exigiu a sua superação através da pergunta sobre o seu valor e a resposta sobre sua ineficácia para a vida.

\section{Humano, demasiado humano como suspeita do valor moral do altruísmo}

Afora essas questões de método ou de estratégia, e cientes dessa mudança interpretativa sobre suas próprias formulações filosóficas, atenhamo-nos à crítica de Nietzsche ao valor do altruísmo, tal como ela aparece em Humano, demasiado humano. A questão central é, obviamente, o fundo metafísico sobre o qual Schopenhauer tinha apoiado as sua tese sobre o fundamento da moral: retirado esse "fundo", não restaria senão o próprio egoísmo em suas apresentações no reino da existência concreta, humana, demasiado humana. Aí, o que se vê, é simplesmente os motivo de autoconservação e autofruição de todos os indivíduos e todas as manifestações aparentemente altruístas não passariam de formas gradativas de egoísmo. Do ponto de vista de Nietzsche, portanto, não tendo outra saída, a moral teria de assumir o egoísmo e revitalizá-lo no âmbito da pura necessidade que marca a existência esperando, com isso, alcançar um alívio da culpa tradicional que tornou a vida pesada frente ao valor inalcançado do altruísmo. Chega-se então ao conceito de inocência.

A suspeita de Nietzsche em relação aos valores morais se revela como uma tentativa de retirar o tom milagroso que envolve e dá sacralidade à moralidade: "serão milagres esses atos da moral" (HH, 57) é a pergunta fundamental que, aliás, guia não só a pergunta sobre a moralidade, mas também a pergunta sobre a religião e sobre a arte, (também esta guiada por esse tom milagroso que vulgarmente dá credibilidade à atividade artística). No fundo, diz Nietzsche, boa parte das ações consideradas morais porque guiadas pelo altruísmo, esconde um "amor a algo de si, um pensamento, um anseio, um produto" $(\mathrm{HH}, 57)$ e muito mais isso do que de fato um amor "a algo diferente de si", ou seja, há mais egoísmo do que altruísmo na maior parte dessas ações. Trata-se de uma "inclinação por algo (desejo, impulso, anseio)" (HH, 57) e, portanto, ceder a ela não é altruísmo e por isso, o homem, afirma Nietzsche, na moral, "não se trata a si mesmo como individuum, mas como dividuum" (HH, 57), ou seja, ele "divide seu ser sacrificando uma parte à outra" (HH, 57), o que significa que ela age, muitas vezes segundo os seus desejos e ideias, algo diferente de si mesmo. Os casos citados são: um autor que quer ver um adversário expor melhor um tema, uma jovem que deseja ver 
sua fidelidade testada pela infidelidade do amado, um soldado que dá a vida pela vitória da pátria que é seu maior desejo, a mãe que doa ao filho aquilo do que ela mesma se priva e o mártir capaz de dar a vida em seguimento a outro homem: em todos eles o motivo da ação não é o altruísmo, mas o egoísmo de ver realizada plenamente um desejo, um impulso ou uma ideia. Trata-se de uma perspectiva que tenta explicitar o egoísmo como motivo das ações humanas, enquanto demonstra que, inversamente, até agora a moralidade tem valorizado a impessoalidade e a abnegação de si como valor absoluto. A negação do egoísmo na moral veio acompanhada de uma negação do que é pessoal e de uma hipertrofia do valor dos costumes (cf. $\mathrm{HH}, 96$ ), do seguimento dos costumes e do serviço à maioria e ao conjunto.

No aforismo 50, de Humano, demasiado humano, encontramos uma reflexão arguta de Nietzsche a respeito do "desejo de suscitar compaixão" por parte dos sofredores. Referindo-se a La Rochefoucauld, que aconselhava a compaixão apenas ao povo, sempre guiado pelas paixões, e não aos homens de razão, pois ela enfraqueceria a alma, Nietzsche afirma que o desejo de compaixão, manifestado por um infeliz, acaba sendo apenas um sintoma de seu egoísmo, já que a "ostentação da infelicidade" não teria outro objetivo senão "causar dor nos espectadores" tornando a compaixão que este expressam "um consolo para os fracos e sofredores" apenas no sentido de que ela faz com que estes percebam "ter ao menos um poder ainda, apesar de toda a sua fraqueza: o poder de causar dor" (HH, 50). Trata-se, então, de um sentimento de prazer conquistado pelo sofredor, que se sente "ainda importante o suficiente para causar dores ao mundo" ( $\mathrm{HH}, 50)$, "de modo que a sede de compaixão é uma sede de gozo de si mesmo, e isso à custa do próximo" (HH, 50) e, então, um sintoma do corrente egoísmo que marca todas as ações humanas. Note-se como aqui, Nietzsche ainda continua bastante ligado, embora apenas na superfície, às teses schopenhaurianas: trata-se daquele prazer em fazer mal a outrem que guia muitas ações dos homens, ainda que poucos estejam dispostos a concordar com isso. Nietzsche encerra o fragmento fazendo referência a Prosper Mérimée: "Saibam também que não há nada mais comum do que fazer o mal pelo prazer de fazê-lo".

O mesmo tema reaparece no aforismo 103 de Humano, demasiado humano, no qual Nietzsche fala do prazer advindo da maldade, ou seja, do fazer mal a outrem, já que o sofrimento alheio também mostra a superioridade do algoz. Passa-se, assim, da perspectiva do prazer do sofredor, ao ponto de vista do executor. Pergunta Nietzsche: "Então o imoral consiste em ter prazer a partir do desprazer alheio?" (HH, 103). E fazendo uma relação direta com as teses de Schopenhauer, ironiza: "É diabólica a satisfação com o mal alheio, com quer Schopenhauer?" 
E mais adiante: "Em si mesmo o prazer não é bom nem mau; de onde viria a determinação de que, para ter prazer consigo, não se deveria suscitar o desprazer alheio? Unicamente do ponto de vista da utilidade, ou seja, considerando as consequências, o desprazer eventual, quando o prejudicado ou o Estado que o representa leva a esperar punição e vingança [...]" (HH, 103). Ou seja, por temer as consequências de desprazer contra si é que alguém não faria o mal contra outrem. Ou ainda: a maldade não tem outro objetivo e sentido senão o prazer que pode doar ao indivíduo e há nisso algo daquela inocência infantil já apontada anteriormente por Nietzsche. Para Nietzsche, a conclusão seria a seguinte: "Assim como a maldade não visa o sofrimento alheio em si, como já disse, também a compaixão não tem por objetivo o prazer do outro" (HH, 103). O argumento, ainda que bastante provocativo e controverso, tem como intenção mostrar que a compaixão carrega consigo apenas um sentimento de prazer, ou melhor, mais especificamente, dois sentimentos de prazer: em quem recebe e em quem doa ou ainda, o prazer da emoção com a desgraça e com a satisfação advinda do sentimento de superioridade de seu exercício. "E é, desta forma, fruição de si mesma: primeiro como prazer da emoção, a espécie de compaixão que há na tragédia, e depois, quando impele à ação, como prazer da satisfação no exercício do poder" (HH, 103). A tese de Nietzsche é, portanto, de que a compaixão não tem em si nada de grandioso, em termos morais, mas ao contrário, "à parte alguns filósofos, os homens sempre [a] situaram num nível baixo, na hierarquia dos sentimentos morais; e com razão" (HH, 103).

O tema do prazer da crueldade é retomado também em Aurora, § 18, no qual Nietzsche analisa como esse prazer teve importância social em situações de guerra ou em comunidades pequenas e ameaçadas ou mesmo para almas "endurecidas na privação e na moralidade" (A, 18), pois é na crueldade que muitas vezes se encontra a capacidade de ser inventivo. Por isso, "a crueldade está entre as mais velhas alegrais festivas da humanidade" (A, 18), estando ligada também aos cultos a divindades (como se imaginássemos que, se nós nos alegramos com isso, certamente os deuses também), que favorecem uma apologia do "sofrimento voluntário" e do "martírio deliberado" (A, 18) que tem alimentado muitas religiões, em especial a cristã. Sofrer torna-se um requisito de fé, pois se acredita que os deuses podem tratar com mais benevolência os sofredores do que os alegres: "é assim que entra, na noção do 'homem mais moral' da comunidade, a virtude do frequente sofrer, do duro viver, da privação, da cruel mortificação" (A, 18). Nietzsche insiste que esse sofrimento não tem como objetivo a disciplina e o autodomínio em busca da felicidade individual, mas se apresenta apenas em função do bem da comunidade, para que ela tenha "bom aroma junto 
aos deuses maus, subindo até eles como os fumos de um permanente sacrifício no altar" (A, 18), a fim de dar-lhes prazer.

A compaixão esteve, junto com a benevolência e seus similares (cf. $\mathrm{HH}$, 96) sempre no topo da lista do que é compreendido como "bom", segundo Nietzsche, justamente porque esse bom é compreendido como um "bom para algo", ou seja, a partir do ponto de vista de sua utilidade para o coletivo, para a sustentação dos costumes que expressam as necessidades comuns de todos os homens. O "dano voluntário ao próximo" $(\mathrm{HH}, 96)$ é tido, no geral, como ofensivo à coletividade e, por isso, tido como imoral e como mau. Como a lei e os costumes são a expressão dessa utilidade, ou seja, estão a serviço da conservação de "uma comunidade, um povo" (HH, 96), então, segundo Nietzsche "'egoísta' e 'altruísta' não é a oposição fundamental que levou os homens à diferenciação entre mora e imoral, bom e mau, mas sim estar ligado a uma tradição, uma lei, ou desligar-se dela" (HH, 96). Em Aurora o seguimento dos costumes (como moralidade do costume) é colocado novamente em xeque sob a mesma premissa: o cumprimento dos costumes não garante a moralidade, porque ela reduz a atividade ao cumprimento da regra tradicional: "a moralidade não é outra coisa (e, portanto, não mais) do que obediência a costumes, não importa quais sejam; mas costumes são a maneira tradicional de agir e avaliar" (A, 9). Ou seja, o mero seguimento dos costumes além de engessar os comportamentos, anula a sua capacidade de responder criativamente às diferentes situações vitais, anula a capacidade, portanto, de criar a moral para o fortalecimento da vida. Nesse caso, quanto mais costume menos moral e quanto mais moral, menos liberdade: "O homem livre é não-moral" (A, 9) nesse sentido.

Romper com o costume é agir por si mesmo, em tudo "depender de si, não de uma tradição" (A, 9). Eis a moral por excelência. Nota-se assim, de que forma Nietzsche promove uma revitalização moral do egoísmo: só a autoafirmação, o exercício do que é "'individual', 'livre', 'arbitrário', 'inusitado', 'inaudito', 'imprevisível'” (A, 9) pode conter os requisitos que tornam a moral a favor da vida. só o egoísmo pode possibilitar a moral no sentido exato, quando uma "ação é realizada não porque a tradição ordena, mas por outros motivos (a utilidade individual, por exemplo)" $(\mathrm{A}, 9)$. A tutela da tradição impede a moral porque exige que se observe os preceitos "sem pensar em si como indivíduo" (A, 9). Ao contrário, a verdadeira moralidade não está no ato de respeitar o costume, mas em legislar e de "criar costumes" (A, 9).

Nietzsche descreve nessa passagem dois momentos da moralidade dos costumes até agora: o primeiro é quando ocorre o simples cumprimento da lei, que o indivíduo carregue a toda lei a toda parte e sempre encontre oportunidades de observá-la; o segundo, quando não só ele obedece a 
lei, mas quando ele se sacrifica por ela, dando a ideia de que "o mais moral é aquele que mais sacrifica ao costume" (A, 9), de forma não a prova a utilidade dessa obediência, mas a própria eficácia da lei. Então, é o sacrifício do indivíduo, principalmente pelo autodomínio e pela abstinência (leia-se, negação de si) que passa a ser o requisito máximo da moralidade dos costumes, de modo que "cada ação individual, cada modo de pensar individual provoca horror" (A, 9) e logo os "espíritos mais raros, mais seletos, mais originais da história" (A, 9) acabaram por serem banidos como indesejados ou inconvenientes, porque nela "toda espécie de originalidade adquiriu má consciência" (A, 9). No fim, "todo aquele que subverteu a lei de costume existente foi tido inicialmente como homem mau" (A, 20). Por isso, escreve o filósofo, a moralidade está articulada com a estupidez: "a moralidade opõe-se ao surgimento de novos e melhores costumes: ela torna estúpido" (A, 19).

Além disso, quando se transforma a compaixão e a piedade em critério moral por excelência, é preciso que também se deseje a manutenção das situações emergenciais de dor e sofrimento que a demandam. A mesma moral que propõe o altruísmo como fundamento da moralidade é também aquele que anuncia a conservação das condições que a exigem.

Trata-se, no fundo, de uma anulação do indivíduo, já que a regra moral por excelência passa a ser, em sociedade, "mostrar-se como igual, inserir-se, diminuir-se" (A, 26), de tal forma que "o indivíduo se esconde na generalidade do conceito 'homem' ou na sociedade, ou se adéqua a governantes, classes, partidos, opiniões de época ou do ambiente" (A, 26). Aliás, Nietzsche evidencia que o conceito de "homem" não passa de uma "exangue abstração" ou mesmo de uma "pálida ficção universal" (A, 105) mas que tem efeito determinante sobre a negação do "ego real" ${ }^{\text {, na }}$

${ }_{6}$ O uso dessa expressão não deve nos induzir à ideia de que Nietzsche tem em vista uma "realidade" pura o Eu que deveria ser desvelada. O uso aqui é estritamente contextual e está contraposto ao que há de ficcional no conceito "homem". O que deve ser notado é o quanto o conceito (como aquilo que nos chega à consciência de nós mesmos) é tão só algo ficcional. Essa questão se esclarece no aforismo 115 de Aurora, intitulado "O assim chamado 'Eu'" no qual o filósofo destaca o fato de que a linguagem não dá conta de precisar os "graus mais suaves e medianos e mesmo os graus mais baixos, continuamente presentes" (A, 115) que escapam das definições, todas elas limitadas aos graus "extremos" e "superlativos". Por isso, a parcela de nosso Eu que aparece "nenhum de nós o é; por essas manifestações grosseiras, as únicas que nos são conhecidas, nós nos conhecemos mal" (A, 115). Por isso, o "mundo do 'sujeito'" $(A, 116)$ não é mais do que um mundo desconhecido, que evidencia aquilo que é difícil de ser compreendido e aceito no geral: que permanecemos ignorantes a respeito de nós mesmos na maior parte do tempo. Ora, se o autoconhecimento é uma das premissas da moralidade, a confusão sobre nós mesmos acaba levando ao desconhecimento sobre "como se produz a ação humana" (A, 116). Trata-se de um "nefasto preconceito" e de um "'profundíssimo erro' segundo o qual, 'o conhecimento correto é necessariamente acompanhado da ação correta" (A, 116). Nietzsche propõe justamente o inverso, ou seja, que "a ponte do conhecimento ao ato não foi lançada nem uma vez até hoje" e que "os atos não são jamais aquilo que nos parecem ser" (A, 116). Nietzsche, na conclusão desse aforismo, cita Schopenhauer, incluído entre os defensores de um "realismo moral" que via a ação como aquilo que ela parecia ser ao agente. 
medida em que este (o único "a ele acessível e por ele examinado" [A, 105]) teria o poder de "aniquilá-la" (A, 105). O ego próprio não é cultivado quando se cultiva apenas aquilo que é um "fantasma de ego" guardando na definição generalista de homem. No fim, toda moral dos costumes (e essa tem sido a regra de toda a moral ocidental) acaba por condenar o egoísmo e essa é uma exigência lógica de sua estruturação.

O filósofo acrescenta ainda que esse cumprimento da lei é fonte de um prazer e que o hábito (enquanto cumprimento do costume) traz gozo, fazendo com que o costume seja "a união do útil com o agradável" ( $\mathrm{HH}$, 97), ou seja, tanto nele está a utilidade para o coletivo quanto o prazer pessoal de quem o cumpre sem reflexão. Cumprir o costume aparece como a única possibilidade para o alcance do bem.

Ao contrário disso, "todas as 'más' ações são motivadas pelo impulso de conservação ou, mais exatamente, pelo propósito individual de buscar o prazer e evitar o desprazer" (HH, 99). Nietzsche contorna as teses schopenhaurianas para afirmar que o grande engano que está por trás das afirmações da moralidade de determinadas ações é o erro do livrearbítrio: "As más ações que atualmente mais nos indignam baseiam-se no erro de [imaginar] que o homem que as comete tem livre-arbítrio, ou seja, de que dependeria de seu bel-prazer não nos fazer esse mal" (HH, 99). Ou seja, a crença de que alguém faz assim porque quer fazê-lo ou porque escolheu fazê-lo funda a indignação e suscita o ódio dos espectadores: porque julgamos que alguém é livre e, portanto, responsável por esses atos. A coerção individual em busca da conservação é uma prerrogativa do indivíduo que antecede o Estado. Este, por sua vez, é o único lugar no qual se pode fazer de moralidade, porque nele o indivíduo é submetido, retirado de seu isolamento e reunido em associação (cf. HH, 99). Antes dele, ou fora dele, não se pode falar em ações morais avaliadas pela via do costume, cujo sentido, como vimos, é a utilidade coletiva. Do ponto de vista da conservação do indivíduo, as chamadas más ações seriam, portanto, inocentes. A ideia de inocência é contraposta por Nietzsche à de responsabilidade (esta um derivação da ilusão do livre-arbítrio). É comum, afirma o autor, que muitas vezes o mal feito a outrem passe despercebido, porque de fato não se conhece bem as consequências das ações. trata-se da "falta de imaginação" $(\mathrm{HH}, 101)$ que muitas vezes nos acomete. Por causa dela, muitas vezes, "O egoísmo não é mau, porque a ideia de 'próximo' - a palavra é de origem cristã e não corresponde à verdade - é muito fraca em nós; e nos sentimos em relação a ele, quase tão livres e irresponsáveis quanto em relação a pedras e plantas" $(\mathrm{HH}$, 101). Porque não temos acesso ao que o outro é, à suas dores ou mesmo à intensidade de seu sofrimento causado por nós, acabamos sendo inocentes em relação a ele. "Saber que o outro sofre é algo que se aprende, 
e que nunca pode ser aprendido inteiramente", tal como nunca podemos ser culpados ou responsabilizados inteiramente por um ato sobre o qual não temos completo conhecimento de suas consequências. O que nos faz acreditar na imoralidade de um ato é justamente a suposição da vontade livre (cf. HH, 102), ou ainda, a diferenciação entre a liberdade e a necessidade. Para Nietzsche, trata-se de um erro, pois muitas vezes a autoconservação (portanto, a necessidade) é o motor das ações (por exemplo, as de legítima defesa, admitidas por quase todas as morais).

Admitir a legítima defesa leva à pergunta sobre a existência de um comportamento por pura maldade, ou uma deliberação de "causar dano intencionalmente" ( $\mathrm{HH}, 104)$, algo só admitido quando se pensa na autoconservação, ou seja, quando "está em jogo nossa existência ou segurança" (HH, 104). Este é um caso no qual não poderíamos reconhecer algo imoral. Outro caso seria quando desconhecemos os danos advindos da nossa ação ou, mais especificamente, quando causamos danos de forma involuntária, de forma inocente como no caso das crianças. Tratase sempre, no fim, da luta pela vida que pode incluir a luta pelo prazer.

Chega-se, então, ao final do capítulo Contribuição à história dos sentimentos morais, de Humano, demasiado humano, à formulação de uma verdadeira doutrina da inocência cujo ponto de partida é, assim, a negação tanto do livre-arbítrio quanto da responsabilidade dele advinda, porque Nietzsche faz ver que todas as suas ações nascem da "natureza e da necessidade" (HH, 107) e, portanto, não poderiam ser submetidas às avaliações morais. Por isso, "tal como ele [o homem do conhecimento] se coloca diante das plantas, deve se colocar diante dos atos humanos e de seus próprios atos" (HH, 107). Nota-se como aqui realiza-se aquilo que fora dito por Rée a respeito da proximidade entre o homem natural e o homem físico: agora a moral precisa ser pensada a partir do reino da necessidade e da natureza, como efeitos e sintomas ligados à necessária autoconservação dos indivíduos, prescindindo das avaliações de bem ou mal. Não há mérito e nem demérito nelas: "Entre as boas e as más ações não há uma diferença de espécie, mas de grau, quando muito" (HH, 107). O que guia essas ações é apenas o egoísmo, lido por Nietzsche nesse capítulo de Humano, demasiado humano, como desejo de autofruição do indivíduo. Em todos os seus atos é ou o prazer ou o medo de perdê-lo que estão agindo e sua avaliação moral depende simplesmente do "grau de inteligência" $(\mathrm{HH}, 107)$ que está decidindo sobre elas. É por pouca sabedoria que a humanidade ainda permanece no âmbito tradicional da moral, portanto. “Tudo é necessidade - assim diz o novo conhecimento: e ele próprio é necessidade" (HH, 107), e é essa a verdadeira sabedoria que está acima da moralidade: se tudo é necessidade, é porque também "tudo é inocência: e o conhecimento é a via para compreender essa inocência" (HH, 107). No 
âmbito da moral tudo está em fluxo e foi necessário passar por todos os descaminhos e erros de avaliação da moral para conquistar essa liberdade plena, condensada na ideia da criação (ou do nascimento) de um "homem sábio e inocente (consciente da inocência)" do qual o homem limitado, "tolo, injusto, consciente da culpa" é não o posto, mas o precursor.

\section{Considerações finais}

Schopenhauer aparece para Nietzsche como o homem do saber restrito e limitado ao campo da moralidade, porque sua filosofia cresceu sobre o erro do fundamento metafísico. Ao recusar essa hipótese, Nietzsche chega à afirmação de que a compaixão é sempre guiada pela necessidade de fruição e que é essa, uma forma de egoísmo, cuja afirmação conduz à ideia de autoconservação e autofruição, bases para uma doutrina da inocência. Se todas as ações humanas são guiadas pela natureza e pela necessidade, então a nova sabedoria faz ver que a meta da moral é a inocência e aí residiria o verdadeiro conhecimento, aquele que, conforme o anúncio do primeiro aforismo desse capítulo (o 35), chegaria ao alívio da existência. Pela inocência Nietzsche libera as forças alegres da existência, retirando o seu fardo por uma análise psicológica que faz ver que esse peso não passa de resultado de erros interpretativos a respeito dos fenômenos humanos.

No fundo, a afirmação de Nietzsche está ligada ao diagnóstico de um erro na interpretação do homem a respeito de si mesmo, descrito como motivado por uma "falha no espelho" ( $\mathrm{HH}, 133)$ que refletiu de si uma imagem que lhe "pareceu obscura e odiável" (HH, 133). Como resultado desses erros de interpretação, o homem em geral alimentou um "sentimento de autodesprezo" $(\mathrm{HH}, 134)$ sobre si mesmo. O "feio" de si mesmo que precisou ser negado e melhorado pela via da moralidade não é outro senão o egoísmo: ao negar essa característica em si mesmo, o homem o fez sob a invenção de um ser absolutamente altruísta, que aparecem a Nietzsche como "mais fabuloso do que o pássaro Fênix" já que "num exame rigoroso o conceito de 'ação altruísta' se pulveriza no ar" (HH, 133) e acrescenta que

jamais um homem fez algo apenas para os outros e sem qualquer motivo pessoal; e como poderia mesmo fazer algo que fosse sem referência a ele, ou seja, sem uma necessidade interna (que sempre teria seu fundamento numa necessidade pessoal)? Como poderia o ego agir sem ego? (HH, 133)

A posição de Nietzsche acaba por colocar em xeque também a própria ideia de Deus como "todo amor", fonte de inspiração para a moralidade que anuncia o altruísmo como fundamento da moralidade. Mesmo o amor 
não passaria de uma busca pela autofruição. Se alguém "desejasse ser todo amor" (HH, 133) esse desejo, no fundo, seria apenas expressão de seu egoísmo e, além disso, haveria nela uma suposição de que "o outro seja egoísta o bastante para sempre aceitar esse sacrifício, esse viver para ele" (HH, 133). A mesma argumentação é retomada no aforismo 90 de Aurora, intitulado "Egoísmo contra egoísmo", para explicitar de que forma a luta contra o egoísmo que se ampara seja na ideia de Deus ou na ideia de um fundamento para a moral não passariam de outra espécie de egoísmo, já que os seus arautos não podem imaginar viver sem o hábito dessas noções e por isso, por um desejo próprio e por "presunção", acabam impondo essa necessidade - que é sua - sobre todos os demais, não admitindo que "outros sentissem de maneira oposta" ou que "não quisessem viver sob as condições desses dois artigos de fé" (A, 90).

A revitalização moral do egoísmo é um dos temas centrais de Aurora, principalmente no livro II. A análise parte de uma constatação: o altruísmo, como "glorificação do pensar em outros, do viver pra outros" (A, 131) é uma "moda moral" recente que teria feito "grandes prodígios da moralidade como Epicuro" simplesmente serem chamados de "imorais, pois lutaram com todas as forças por seu ego e contra a empatia com os outros" (A, 131). Ao lado dessa primeira constatação, Nietzsche apresenta outra: o ódio a si mesmo só tem uma saída, o amor ao outro. Ou seja, o amor ao outro (o altruísmo) tem uma base bastante sórdida: o ódio em relação ao eu. $E$ isso não passa das "últimas ressonâncias do cristianismo na moral" (A, 132), já que mesmo Schopenhauer, não seria senão uma "antessala do cristianismo" (KSA 8, 30 [9], de 1878, p. 523). Essa perspectiva é retomada no fragmento seguinte, no qual Nietzsche explicita a sua impressão a respeito dessa mudança, considerada por ele como a mais ampla "que o cristianismo produziu na Europa" (A, 132). A mudança, ou o efeito são apresentados como "resíduos de disposições de espírito cristã" como um resultado secundário do valor egoísta da "salvação pessoal", cujo resultado seria a utilização do amor ao próximo como dispositivo ético que conduziria ao seu alcance. Em outras palavras, o modismo que viu "o indivíduo de ações simpáticas, desinteressadas, sociais, de utilidade geral" como "homem moral" (A, 132) está baseado numa busca egoísta pela salvação pessoal e para isso se utiliza da dor alheia. Mesmo os chamados "livre-pensadores" (entre os quais Nietzsche cita Voltaire e Comte, Schopenhauer e Mill) teriam sido influenciados por esta regra: compensar e até mesmo, conforme o verbo usado por Nietzsche, justificar o seu desprendimento e ou sobrepujá-lo em relação aos dogmas cristãos com o "culto do amor aos homens". Esses autores teriam superado o "os cristãos em cristianismo" (A, 132). A teoria schopenhauriana da compaixão, assim, teria sido "apenas um eco" das 
doutrinas cristãs, alardeada grandemente pela Revolução Francesa, tendo como "solo comum" o cristianismo, de tal forma que "agora parece que faz bem a todos ouvir dizer que a sociedade está em vias de adequar o indivíduo às necessidades gerais e que a felicidade e ao mesmo tempo o sacrifício do indivíduo está em sentir-se um membro útil e um instrumento do todo" (A, 132). Mesmo divergentes sobre onde "buscar esse todo", as teorias são concordantes "em exigir que o ego negue a si mesmo, até adquirir novamente, na forma da adequação ao todo, seu sólido círculo de direitos e deveres" ou seja, "pretende-se nada menos - seja ou não admitido - que uma radical transformação, uma deliberação e anulação do indivíduo" (A, 132). A condenação da "existência individual" é a marca da cultura e a hostilidade geral a tudo o que é pessoal passa a ser a exigência para a formação de "corpos grandes e seus membros", ou seja, estruturas nas quais os indivíduos tenham status secundário. Para isso a "empatia individual e o sentimento social" não passariam de "impulsos auxiliares" (A, 132). Uma observação irônica de Nietzsche é dirigida, no final desse fragmento, a Kant, estando, inclusive, entre parênteses no texto: "(Kant ainda está fora desse movimento: ele ensina expressamente que devemos ser insensíveis ao sofrimento alheio, para que a nossa beneficência tenha valor moral - o que Schopenhauer, muito irritado, como se pode compreender, chama de a insipidez kantiana)" (A, 132). Obviamente Nietzsche está discutindo aqui as posições críticas de Schopenhauer na sua avaliação do fundamento da moral kantiana, à qual acusa de estar reduzida à lógica da obediência racional às regras, e carecer se um fundamento eficaz, que estaria no sentimento da compaixão.

Essa posição acaba por aliviar também o homem da culpa e do remorso que advém dessa má interpretação de si mesmo: eis o resultado moral da conquista da verdadeira sabedoria, a sabedoria da inocência, nascida da necessidade incondicional que dá origem a todas as ações humanas. Se, por fim, a pessoa conquistar e incorporar totalmente a convicção filosófica da necessidade incondicional de todas as ações e de sua completa irresponsabilidade, desaparecerá também esse resíduo de remorso" (HH, 133). Eis o grande amor, o novo amor, a nova "autoestima", o "prazer consigo mesmo", o "bem-estar com a própria força": "o homem sente que de novo ama a si mesmo"(HH, 134).

\section{Referências}

FAZIO, Domenico M. (Org.). La scuola di Schopenhauer: testi e contesti. A cura del Centro interdipartimentale di ricerca su Arthur Schopenhauer e la sua scuola dell'Università del Salento. Lecce: Pensa Multimedia, 2009. (Schopenhaueriana, 2).

JANAWAY, C. Schopenhauer. São Paulo: Loyola, 2003. (Mestres do Pensamento).

LEFRANC, J. Compreender Schopenhauer. Petrópolis: Vozes, 2005. 
NIETZSCHE, F. Aurora. Reflexões sobre os preconceitos morais. Trad. de Paulo César de Souza. São Paulo: Cia. das Letras, 2004.

. Ecce Homo. Como alguém se torna o que é. Trad. notas e posfácio Paulo César de Souza. 2. ed., 3. reimp. São Paulo: Companhia das Letras, 1995.

. Genealogia da Moral. Uma polêmica. Trad. de Paulo César de Souza. São Paulo: Cia. das Letras, 2002.

. Humano, Demasiado Humano. Um livro para espíritos livres. Trad. de Paulo César de Souza. São Paulo: Cia. das Letras, 2000.

. Humano, Demasiado Humano II. Trad. de Paulo César de Souza. São Paulo:

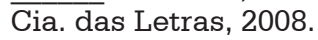

. Obras incompletas. Trad. Rubens Rodrigues Torres Filho. São Paulo: Abril

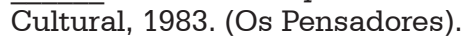

. Sämtliche Briefe. Kritische Studienausgabe (KSB). Herausgegeben von Giorgio Colli und Mazzino Montinari. München/Berlin/New York: dtv/Walter de Gruyter \& Co., 1986. (8 Bänden).

. Sämtliche Werke. Kritische Studienausgabe (KSA). Herausgegeben von Giorgio Colli und Mazzino Montinari. München/Berlin/New York: dtv/Walter de Gruyter \& Co., 1988. (15 Einzelbänden).

RÉE, Paul. Basic writings. Transleted and edited by Robin Small. Illinois: University of Illinois Press, 2003. (International Nietzsche Studies).

. Gesammelte werke (1875-1885). Hubert Treiber (Org.). Berlim: de Gruyter, 2004.

SCHOPENHAUER, Arthur. O Mundo como Vontade e como Representação. Trad. Jair Barboza. São Paulo: Ed. UNESP, 2005.

. Sobre o fundamento da Moral. Trad. Maria Lúcia Mello Oliveira Cacciola. 2. ed. São Paulo: Martins Fontes, 2001.

. Metafísica do amor e Metafísica da morte. Trad. Jair Baboza. São Paulo: Martins Fontes. 2004.

. Parerga e Paraliponema. Tradução de Wolfang Leo Maar. São Paulo, Nova

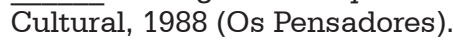

. Sämtliche Werke. Bearbeitet und Heraugegebt von Wolfgang Frhr. Von Löhnheysen. Frankfurt am Main: Suhrkamp, 1998.

STAUDT, Leo Afonso. O significado moral das ações como negação da vontade, para Arthur Schopenhauer. Rev. Filos., 19, 25 (jul./dez. 2007), p. 273-303.

SMALL, Robin. Nietzsche and Rée. Star friendship. Oxford; New York: Oxford University Press, 2007.

. Translator's introduction. In: RÉE, Paul. Basic writings. Transleted and edited by Robin Small. Illinois: University of Illinois Press, 2003. (International Nietzsche Studies). p. xi-liii.

\section{Endereço postal:}

Escola de Educação e Humanidades Prado Velho

Rua Imaculada Conceição, 1155

Curitiba, PR, Brasil

Data de recebimento: 17/06/2013

Data de aceite: 10/07/2014 